\title{
結晶方位差理論に基づく結晶塑性構成式の提案*
}

\author{
倉前宏行 ${ }^{* 1}$, 池谷友規 ${ }^{* 2}$, 森本秀夫 ${ }^{* 3}$ \\ 坂本英俊 ${ }^{* 4}$, 片山傳生 ${ }^{* 5}$, 仲町英治 ${ }^{* 6}$
}

\section{Proposition of a Crystal Plasticity Constitutive Equation Based on Crystallographic Misorientation Theory}

\author{
Hiroyuki KURAMAE ${ }^{* 1}$, Yuki IKEYA, Hideo MORIMOTO, \\ Hidetoshi SAKAMOTO, Tsutao KATAYAMA and Eiji NAKAMACHI \\ ${ }^{* 1}$ Osaka Institute of Technology, Dept. of Technology Management \\ 5-16-1 Omiya, Asahi-ku, Osaka, 535-8585 Japan
}

In this study, we try to reveal the relationship between the plastic deformation and the microscopic crystal misorientation evolution by using the homogenized finite element (FE) procedure with the proposed crystal plasticity constitutive equation. Since plastic deformation of polycrystal sheet metal is greatly affected by its initial and plastic deformed textures, multi-scale FE analysis based on homogenization theory with considering micro polycrystal morphology is required. We formulated a new crystal plasticity constitutive equation to introduce not only the effect of crystal orientation distribution, but also the size of crystal grain and/or the effect of crystal grain boundary for the micro FE analysis. The hardening evolution equation based on strain gradient theory was modified to consider curvature of crystal orientation by using crystallographic misorientation theory. We employed two-scale structure, such as a microscopic polycrystal structure and a macroscopic elastic/plastic continuum. Our analysis code predicts the plastic deformation of polycrystal metal in macro-scale, and simultaneously crystal texture and misorientation evolutions in the micro-scale. The crystallographic misorientation evolution induced by the plastic deformation of polycrystal aluminum alloy was investigated by using the multi-scale FE analysis with new proposed hardening evolution equation. We confirmed the availability of our analysis code employing the new constitutive equation through the comparison with numerical and experimental results of uniaxial tensile problem.

Key Words : Finite Element Method, Constitutive Equation, Crystal Plasticity, Multi-Scale Analysis, Crystallographic Homogenization Method, Misorientation Theory

\section{1. 緒言}

金属材料の塑性変形特性はその微視結晶構造に大きく依存するため ${ }^{(1)}$, 有限要素解析においても実体としての 微視構造を考慮した結晶塑性構成式の導入が必要となる. 結晶塑性変形を対象とした数值解析において，転位の 運動や蓄積の情報を加工硬化則に導入することにより，巨視的な変形と微視的な転位の相互連成を可能としたマ ルチスケール結晶塑性論に関する研究が盛んに行われている(2) (4). 転位論に基づく結晶塑性論で考慮される結晶 欠陥は，Frank-Read 源と呼ばれる転位源から発生した転位が介在物や結晶粒界，他のすべり系からの影響を受け

\footnotetext{
* 原稿受付 2011 年 3 月 3 日

*1 正員，大阪工業大学工学部（干535-8585 大阪府大阪市旭区大宮 5-16-1）

*2 学生員, 同志社大学大学院 ( $=610-0394$ 京都府京田辺市多々羅都谷 1-3)

*3 正員, 古河電気工業 (株) (厂220-0073 神奈川県横浜市西区岡野 2-4-3)

*4 正員, 熊本大学工学部（干860-8555 熊本県熊本市黒髪 2-39-1）

*5 正員, 同志社大学生命医科学部

*6 正員, フェロー, 同志社大学生命医科学部

E-mail: kuramae@dim.oit.ac.jp
} 
た上で堆積したものである。このような結晶欠陥の取り扱いについては，統計的に蓄積する転位（SSD: Statically Stored Dislocation）密度を用いて表す手法, 幾何学的に必要な転位（GND: Geometrically Necessary Dislocation）密 度を用いて表す手法，双方の組み合わせによって表すなど，数多く提案されている．GND密度は，Ashbyによっ て定義された量であり，SSD と同じ次元を有する(5). GND密度に基づくマルチスケール塑性解析は，大橋ら ${ }^{(6) や ~}$ Busso ら (7)によって提案されている. Shizawa らはダイポールと GND の蓄積に関する結晶塑性解析を行っている(8), (9). Fleck らは，SSD 密度と GND 密度を構成則に取り入れることを提案しており ${ }^{(10)}$ ，比嘉らは両転位密度を同 時に考慮して均質化法を組み合わせたマルチスケール結晶塑性解析を行っている(11)．さらに仲町らは，ひずみの 一次勾配と関係づけられる転位密度テンソルを導入した結晶塑性構成式を提案し, 単純せん断実験結果と比較し 良好な結果を得た ${ }^{(12),(13)}$. しかし，これらの非シュミット則に基づく結晶塑性構成式は仮想的な微視構造体モデル に適用されているため，産業界で利用される実材料の塑性加工問題に適用された例は少ない.

本研究では, 微視結晶体と巨視連続体との変形挙動を統一的に記述寸ることが可能なマルチスケール有限要素 法について, 転位蓄積を考慮したひずみ勾配論と結晶方位差理論の関係性に着目し, 結晶方位分布, 結晶粒径, および結晶粒界における方位差を考慮した非シュミット則硬化発展方程式を提案する．SEM-EBSD（Scanning Electron Microscope-Electron BackScatter Diffraction）計測によって得られた結晶方位分布から曲率理論 ${ }^{(14)} に$ 基づい て結晶粒界における硬化や転位蓄積の影響を記述することが可能な硬化発展方程式の提案を行う. 本発展式を採 用し, 塑性変形誘起の結晶方位回転および材料硬化を高精度に予測可能な結晶塑性有限要素解析法の開発を行う.

\section{2. 解析手法}

\section{$2 \cdot 1$ マルチスケール解析方法}

本研究では微視結晶体と巨視連続体の 2 スケールの連成を考慮したマルチスケール有限要素法を採用する (15) (19). 図 1 に示寸ように座標系 $x$ における巨視連続体 $\Omega$ の任意の点で定義された周期性を満足する微視結晶体を 代表体積要素（RVE: Representative Volume Element）とする. 微視結晶体の座標系 $\boldsymbol{y}$ は, 巨視連続体の座標系 $\boldsymbol{x}$ と のスケール比えを用いて次式で表される.

$$
\boldsymbol{y}=\frac{\boldsymbol{x}}{\lambda}, \lambda<<1
$$

均質化法に基づいて定義された全体構造変位速度 $\dot{u}_{i}^{\lambda}$ を以下に示す.

$$
\dot{u}_{i}^{\lambda}(x)=\dot{U}_{i}(x)+\lambda \dot{u}_{i}(x, y)
$$

ここで $\dot{U}_{i}(\boldsymbol{x})$ は巨視連続体における変位速度であり, $\dot{u}_{i}(\boldsymbol{x}, \boldsymbol{y})$ は微視結晶体における摂動を示寸変位速度である. 質量密度 $\rho$, 粘性係数 $v$ を用いて, 巨視連続体の仮想仕事率の原理式はつぎのように表される.

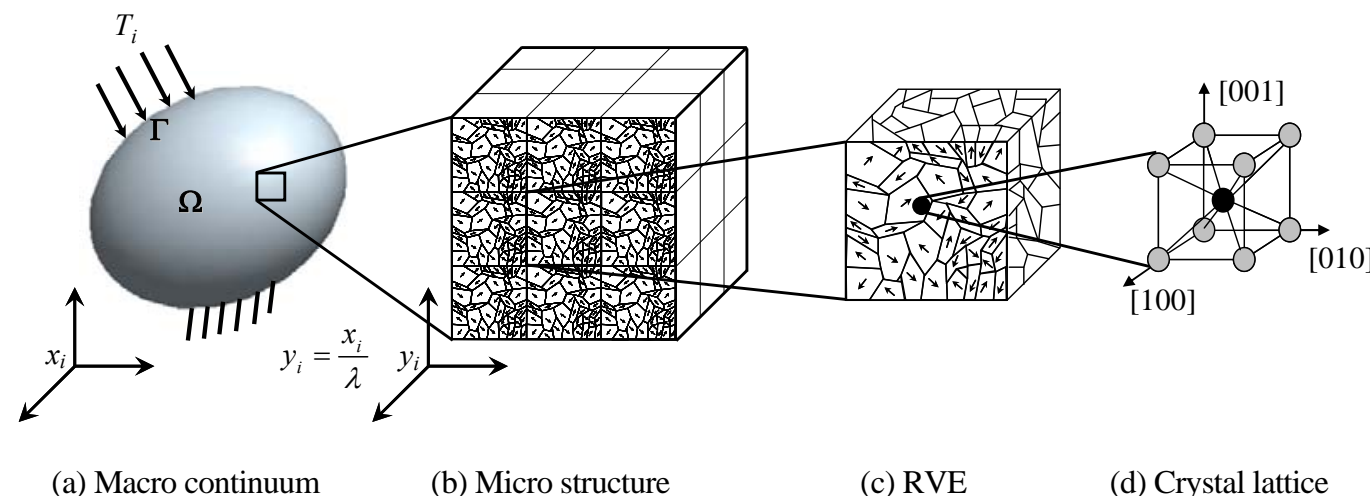
(a) Macro continuum
(b) Micro structure
(c) RVE
(d) Crystal lattice

Fig. 1 Macro continuum and micro polycrystal structures, coordinates $\boldsymbol{x}$ and $\boldsymbol{y}$ 


$$
\int_{\Omega} \rho \ddot{U}_{i}(\mathbf{x}) \delta \dot{U}_{i}(\mathbf{x}) d \Omega+\int_{\Omega} v \dot{U}_{i}(\mathbf{x}) \delta \dot{U}_{i}(\mathbf{x}) d \Omega=\int_{\Gamma} \bar{T}_{i} \delta \dot{U}_{i}(\mathbf{x}) d \Gamma-\int_{\Omega} \sigma_{i j}^{H}(\mathbf{x}) \partial \dot{\delta} \dot{U}_{i, j}(\mathbf{x}) d \Omega
$$

これを解くことによって巨視連続体の変位速度 $\dot{U}_{i}(x)$ が得られ，これを

$$
\dot{u}_{i}(\boldsymbol{x}, \boldsymbol{y})=\frac{\partial \dot{U}_{i}(\boldsymbol{x})}{\partial x_{j}} y_{j},
$$

のようにスケールダウンすることにより任意の点の微視結晶体の変位速度 $\dot{u}_{i}$ を得ることができる.

微視結晶体において, 仮想仕事率の原理式は以下のように表される.

$$
\begin{gathered}
\int_{Y} \rho \ddot{u}{ }_{i}(\boldsymbol{x}, \boldsymbol{y}) \delta \dot{u}_{i}(\boldsymbol{x}, \boldsymbol{y}) d Y+\int_{Y} \dot{v} \dot{u}_{i}(\boldsymbol{x}, \boldsymbol{y}) \delta \dot{u}_{i}(\boldsymbol{x}, \boldsymbol{y}) d Y=-\int_{Y} \sigma_{i j} \delta \dot{u}_{i, j}(\boldsymbol{x}, \boldsymbol{y}) d Y, \\
\delta \dot{u}_{i}(\boldsymbol{x}, \boldsymbol{y})=0 \text {, on the boundary of region } Y .
\end{gathered}
$$

ここで $Y$ は微視結晶体の体積を表す、スケールダウンした変位速度を微視結晶体の周期境界条件として与えて式

（5）を解くことにより，微視結晶体における結晶方位形態に起因する応力分布が得られ，これを体積平均するこ とによって得られる均質化応力

$$
\sigma_{i j}^{H}=<\sigma_{i j}>=\frac{\sum_{e=1}^{N_{e}}\left(\sum_{G=1}^{N_{G}}\left|J_{G}\right| \sigma_{i j}^{G}\right)}{\sum_{e=1}^{N_{e}}\left|J_{e}\right|},
$$

を巨視連続体の運動方程式（3）へフィードバックする．ここで， $\sigma_{i j}^{G}$ は微視結晶体の要素 $e$ の積分点 $G$ における Cauchy 応力, $\left|J_{G}\right|$ は積分点 $G$ の Jacobian, $N_{G}$ は要素内の積分点数, $\left|J_{e}\right|$ は要素 $e$ の Jacobian, $N_{e}$ は微視結晶体の 総要素数である.

\section{$2 \cdot 2$ 結晶方位差理論に基づく弾/結晶塑性構成式}

はじめに Pan, Rice, Needleman, Asaro, Hill らによって提案された結晶体の変形解析理論 ${ }^{(17),(20)(23)}$ の枠組みについ て述べる. すべり系 $a$ に生じるせん断ひずみ速度と分解せん断応力を関係付けた結晶塑性構成式を以下に示す.

$$
\dot{\gamma}^{(a)}=\dot{\gamma}_{0}^{(a)}\left[\frac{\tau^{(a)}}{g^{(a)}}\right]\left[\left|\frac{\tau^{(a)}}{g^{(a)}}\right|\right]^{\frac{1-m}{m}} .
$$

ここで $g^{(a)}$ は基準分解せん断応力, $\dot{\gamma}_{0}^{(a)}$ は基準せん断ひずみ速度, $m$ はひずみ速度感度指数である.

潜在硬化を考慮した基準分解せん断応力 $g^{(a)}$ の硬化発展方程式を以下に示寸.

$$
\dot{g}^{(a)}=\sum_{b=1}^{N} h_{a b}\left|\dot{\gamma}^{(b)}\right| \cdot
$$

ここで $N$ はすべり系の総和であり, 硬化係数 $h_{a b}$ は潜在硬化マトリックスを $q_{a b}$ として

$$
h_{a b}=q_{a b} \frac{d \tau(\gamma)}{d \gamma}+\left(1-q_{a b}\right) \frac{d \tau(\gamma)}{d \gamma} \delta_{a b},
$$

である. 上式において $\gamma$ は各すべり系のすべり量の総和である.さらに $h(\gamma)=d \tau(\gamma) / d \gamma$ はせん断応力-せん断ひず み関係式から次式のように定義される. 


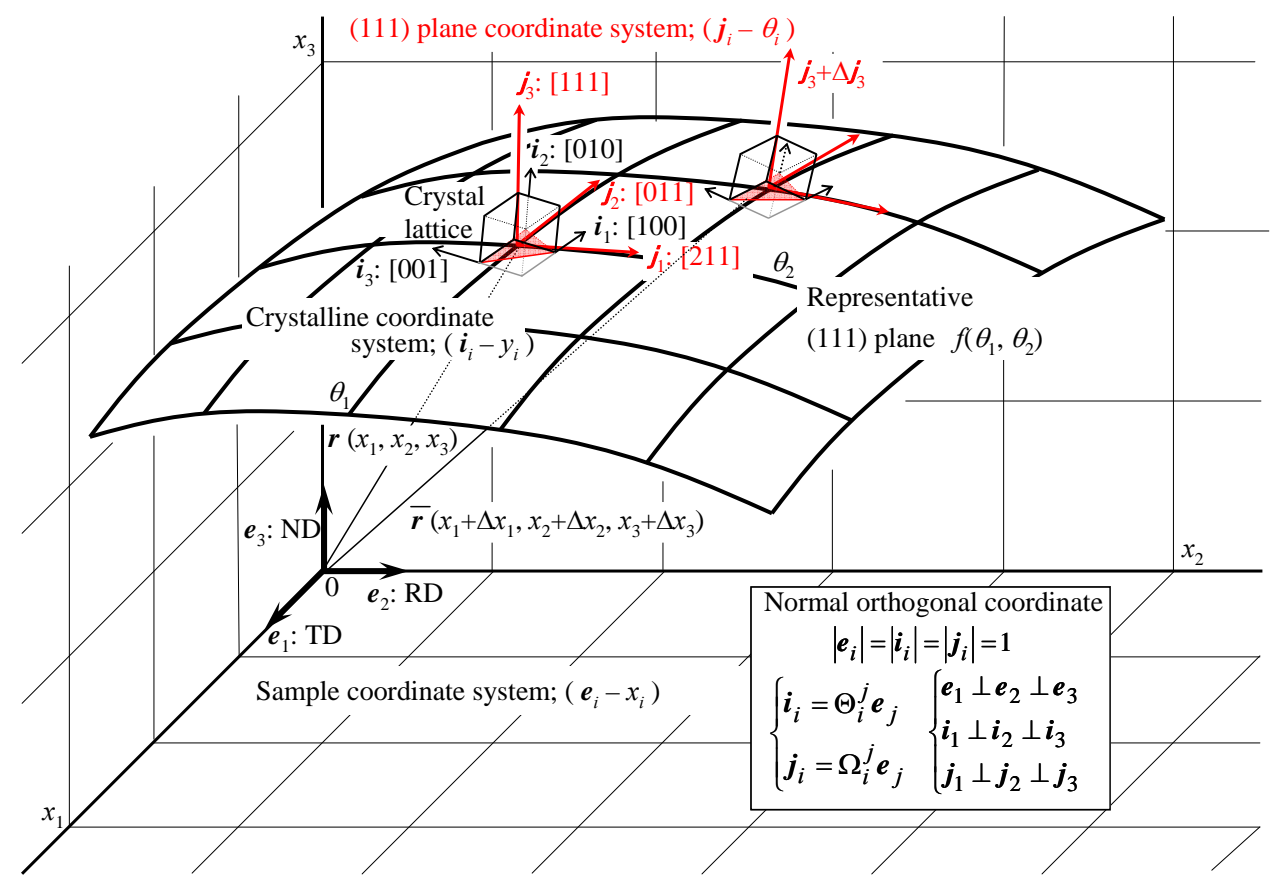

Fig. 2 Definition of the three normal orthogonal coordinate systems

$$
\begin{gathered}
\tau(\gamma)=\tau_{0}+h_{0}\left\{C\left(\gamma_{0}+\gamma\right)\right\}^{n}, \\
\frac{d \tau(\gamma)}{d \gamma}=h(\gamma)=h_{0} n C\left\{C\left(\gamma_{0}+\gamma\right)\right\}^{n-1} .
\end{gathered}
$$

ここで $n$ は硬化指数， $h_{0}$ は初期硬化率， $\tau_{0}$ は初期臨界分解せん断応力， $C$ は硬化係数である.

つぎに結晶方位差の影響を考慮可能なミスオリエンテーションテンソルを算出するため，図 2 に示すように基 準座標系（正規直交デカルト座標系）として，ユークリッド空間における試料座標系 $x_{i}-\boldsymbol{e}_{i}$, 結晶ごとに定義され る結晶座標系 $y_{i}-\boldsymbol{i}_{i}$ ，およびリーマン空間における代表（111）面座標系 $\theta_{i} \mathbf{j}_{i}$ の 3 つを採用する．代表（111）面座標 系を結晶方位差理論の基準とすることにより，(111）すべり面の配向を記述でき，FCC 金属に対する成形性評価 への適用も可能となる. 板面内各々の座標系は座標変換マトリックス $\Theta_{i}^{j}, \Omega_{i}^{j}$ を用いて次式のように変換できる.

$$
\boldsymbol{i}_{i}=\Theta_{i}^{j} \boldsymbol{e}_{j}, \quad \boldsymbol{j}_{i}=\Omega_{i}^{j} \boldsymbol{e}_{j} .
$$

（111）面上における座標系の変化増分 $\Delta \theta_{\beta}$ から（111）面の曲率を求める(14). リーマン空間で定義された基本ベクトル $\boldsymbol{j}_{i}$ を用いて変化増分 $\Delta j_{3}$ を次式のように次式で定義する.

$$
\Delta \boldsymbol{j}_{3}=-b_{\alpha \beta} \mathbf{j}_{\alpha} \Delta \theta_{\beta}
$$

ここで $b_{\alpha \beta}(\alpha, \beta=1,2)$ は第2 基本計量テンソル，つまり曲率テンソルであり，つぎのように表される.

$$
b_{\alpha \beta}=-\frac{\partial \boldsymbol{j}_{3}}{\partial \theta_{\beta}} \cdot \boldsymbol{j}_{\alpha}, \quad \boldsymbol{b}=b_{\alpha \beta} \boldsymbol{j}_{\alpha} \otimes \boldsymbol{j}_{\beta} .
$$

この曲率テンソルは, 曲面の接平面の法線方向変化を表す. 曲率テンソルを基淮座標系により成分表示寸るために座標変換 マトリックス $\Omega_{k}^{\alpha}, \Omega_{l}^{\beta}$ を導入する.

$$
\boldsymbol{b}=b_{\alpha \beta} \Omega_{k}^{\alpha} \Omega_{l}^{\beta} \boldsymbol{e}_{k} \otimes \boldsymbol{e}_{l}=\bar{b}_{k l} \boldsymbol{e}_{k} \otimes \boldsymbol{e}_{l}, \quad \bar{b}_{k l}=-\boldsymbol{j}_{3, l} \cdot \boldsymbol{j}_{k} .
$$


これより得られた曲率テンソル成分 $\bar{b}_{k l} \quad(k, l=1,2,3)$ をミスオリエンテーションテンソル成分と呼び，その第2 不変量であ る相当ミスオリエンテーションKはつぎのように表される.

$$
K=\sqrt{\frac{1}{2} \bar{b}_{k l} \bar{b}_{k l}} .
$$

相当ミスオリエンテーション $K$ は結晶方位および粒径に依存したスカラー量であり, 幾何学的に必要な車云位密度を表現 できる．硬化発展方程式（9）へ導入することで，結晶方位回転，粒界の硬化，およひ転位蓄積を考慮可能な結晶方位差理 論に基づく新硬化発展方程式を定義することができる.

$$
\dot{g}^{(a)}=\left\{\frac{1}{\tanh C_{2}} \tanh \left(C_{1}|K|+C_{2}\right)\right\} \sum_{b=1}^{N} h_{a b}\left|\dot{\gamma}^{(b)}\right| \cdot
$$

ここで，右辺の\{\}内は結晶方位差に依存した硬化を表し， $C_{1}$ と $C_{2}$ は硬化の敏感性，およひ硬化度を表す定数である. 相当 ミスオリエンテーション $K$ の導入によって, 基淮分解せん断応力速度 $\dot{g}^{(a)}$ が強い硬化を示寸ため, 材料固有の結晶粒径, 粒界, および方位分布に依存した構成式となり, 結晶ごとの硬化発展が予測可能となる.

\section{3. マルチスケール有限要素解析結果}

\section{$3 \cdot 13$ 次元EBSD 計測多結晶モデルを用いた二結晶塑性パラメータ同定}

結晶方位差を考慮した構成式においては， $n, \tau_{0}, h_{0}$ といった従来の結晶塑性パラメータに加え, 結晶方位差に基づく硬化 を表すパラメータ $C_{1}, C_{2}$ の同定も行う必要がある. 同定対象はアルミニウム合金多結晶板材 A5182-O とし，室温での単軸 引張り実験から応力ひずみ関係を得た．RVE には実板材料 A5182-O を研磨および SEM-EBSD 計測を繰り返すことによっ て得た多層計測面により構築した 3 次元モデルを採用した. A5182-O材の RVE モデルを図 3 に示寸. RVEの大きさは結晶 方位分布に関して周期性が十分満足される $111 \times 111 \times 111 \mu \mathrm{m}^{3}$ とした. また，RVE の結晶方位点数はこれまでの研究により 1000 方位を妥当と考え導入した ${ }^{(15)}$. なお，すべり系は\{111\}面をすべり面とする計 12 すべり方向を採用した.

この A5182-O のRVE を用いて単軸引張り有限要素解析を行いパラメータ同定を行った結果, 表 1 に示寸結晶塑性パラメ 一タを得た. 図 4 に示すように応力ひずみ関係が実験と良好な一致を示すことを確認した. また，比較のため表 1 と図 4 に従来の結晶塑性パラメータと応力ひずみ線図も示した. この結果より，新規構成式における $\tau_{0}, h_{0}$ は従来のものに比べ低 い值となったが, 新たに設定した材料パラメータ $C_{1}, C_{2}$ によって結晶方位差が結晶のすべりに対する抵抗を示寸基隻分解せ ん断応力の硬化発展方程式に影響し，同様の応力ひずみ曲線を得たと考える.

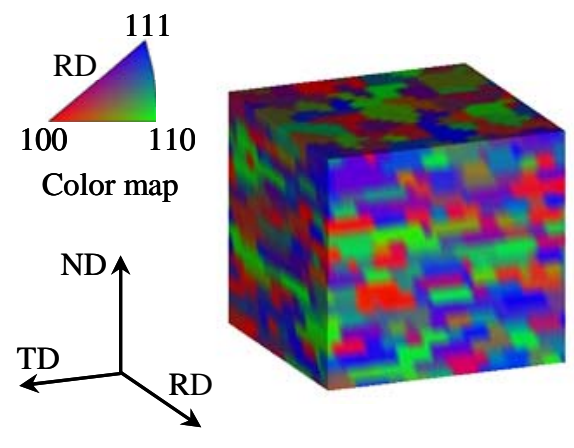

Fig. 3 RVE model of A5182-O $\left(111 \times 111 \times 111 \mu \mathrm{m}^{3}\right)$

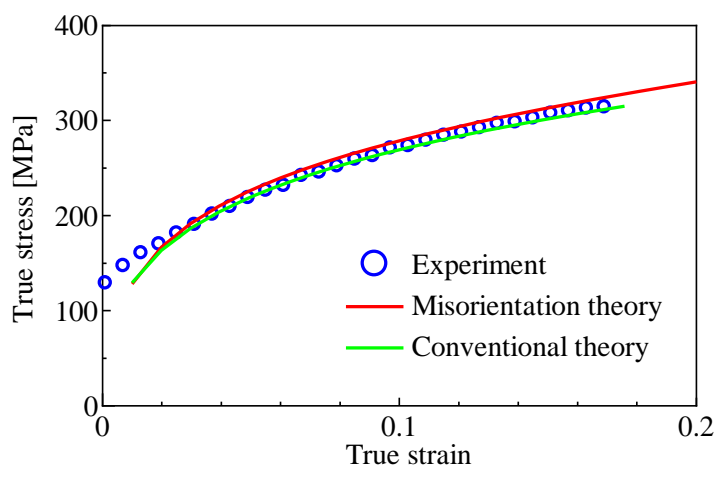

Fig. 4 Relationships between true stress and true strain of experimental and identification results

Table 1 Material parameters obtained by FE analysis

\begin{tabular}{c|c|c|c|c|c|c|c}
\hline \hline Theory & $n$ & $\tau_{0}[\mathrm{MPa}]$ & $h_{0}[\mathrm{MPa}]$ & $C$ & $\gamma_{0}[\mathrm{MPa}]$ & $C_{1}$ & $C_{2}$ \\
\hline Misorientation & 0.19 & 13.0 & 49.0 & 17.0 & 0.10 & 5.0 & 0.8 \\
\hline Conventional & 0.19 & 15.0 & 72.0 & 17.0 & 0.10 & - & - \\
\hline
\end{tabular}




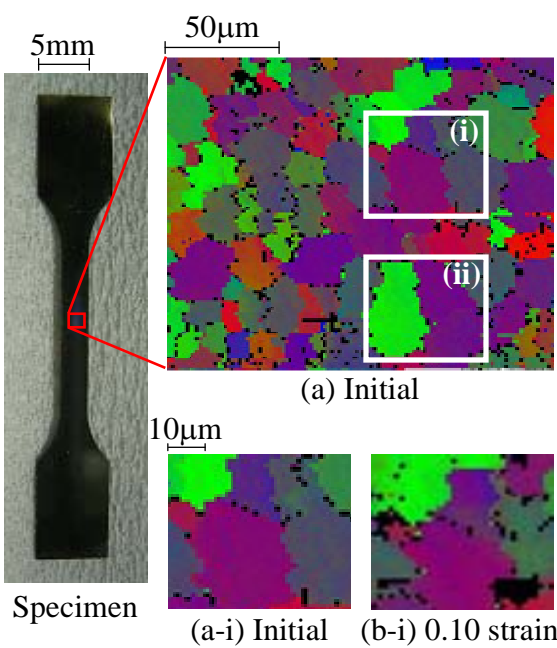

(i) Low tilt angle boundary

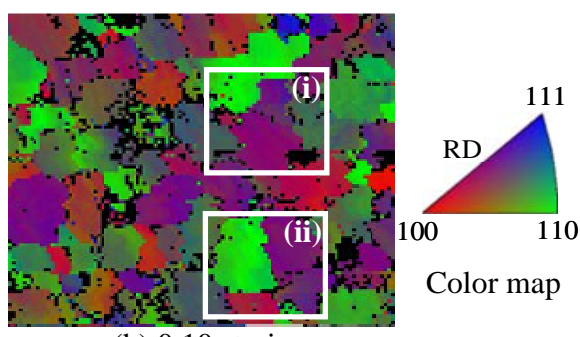

(b) 0.10 strain

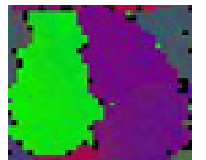

(a-ii) Initial (b-ii) 0.10 strain

(ii) High tilt angle boundary

Fig. 5 Crystal orientation distributions obtained by SEM-EBSD of pure iron in tensile test

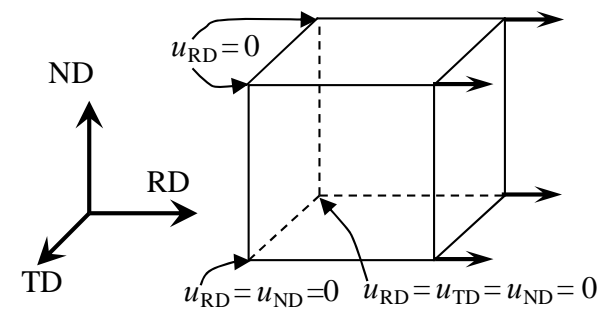

Fig. 6 Boundary conditions of macro FE model

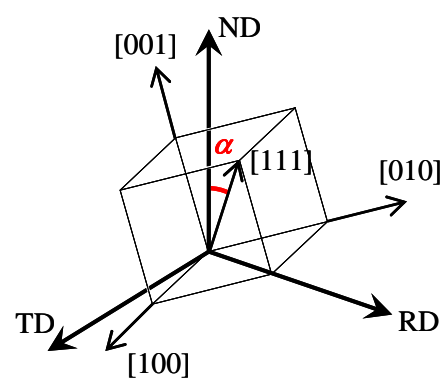

Fig. 7 Definition of crystal orientation angle $\alpha$

\section{$3 \cdot 2$ 解析条件}

図 5 に純鉄多結晶材料について引張り試験前後の SEM-EBSD 結晶方位分布計測結果を示寸. 図 5 (a-i) で確㪊される小 傾角結晶粒界は，塑性変形が進行するにしたがって図5（b-i）のように粒界が消滅している. 一方，図 5 (a-ii) の大傾角結 晶粒界においては, 図 5 (b-ii) に示寸ように結晶粒界が残存していることがわかる. このように塑性変形誘起の結晶方位 回転, 結晶粒界傾角および方位差の発展挙動は, その初期方位および隣敨結晶の方位差に依存し, 粒界の消㓕や残存を引き 起こすことが実験的に明らかである.

そこで, 結晶方位差理論に基づく新硬化発展方程式を導入したマルチスケール有限要素解析によって, 塑性変形誘起の結 晶方位回転，結晶方位差発展，および材料硬化について解析し，提案した構成式の有効性を示寸. 解析は, 図6に示寸よう に，巨視連続体有限要素モデルとして1つの8節点アイソパラメトリックソリッド要素に圧延方向（RD: Rolling Direction） 一強制変位を与えることにより, 単軸引張り状態を設定した. 微視結晶体RVEモデルは, 8 節点ソリッド要素を用いて $5 \times 5 \times 5$ （125 要素， 216 節点， 1000 積分点）に分割し，各積分点に対して結晶方位を割り当てる. RVE モデルの寸法は図 3 に示 した A5182-O の多結晶モデルに合わせた. 結晶方位分布は, 図 7 に示寸板面法線方向 (ND: Normal Direction) と結晶の[111] 方向とのな寸角 $\alpha$ を用いて, 図 8 に示すような結晶方位差の異なる 3 種の双結晶体モデル，および大傾角粒界と小傾角粒界 を混在させた三結晶体モデルを設定した. 結晶方位角 $\alpha$ 設定にあたっては, 表2 に示すように, SEM-EBSD 計測結果より 大傾角粒界および小傾角粒界の各結晶方位をそれぞれ選択し，計測された Bunge のオイラー角 $\varphi_{1}, \Phi, \varphi_{2}$ から結晶方位角 $\alpha$ を 算出した結果, $\alpha=0^{\circ}, 3^{\circ}, 35^{\circ}$ の 3 種を採用した.

初期結晶方位分布に対寸る相当ミスオリエンテーション分布を図 9 に示寸.これより相当ミスオリエンテーション量と図 8 に示寸隣接結晶粒の結晶方位角 $\alpha$ の角度差は比例していることがわかり，粒界を精度よく表現できていると考える.

\section{$3 \cdot 3$ 双結晶体および三結晶体モデルを用いた解析結果}

図 10 に単軸引張り解析によって 50\%ひずみを与えた後の応力ひずみ線図を示す. 3 種の双結晶体モデルのうち, $0^{\circ}-3^{\circ} モ$ 


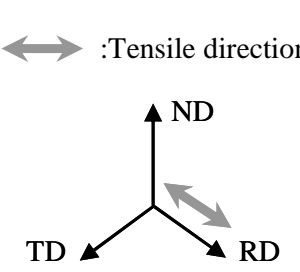

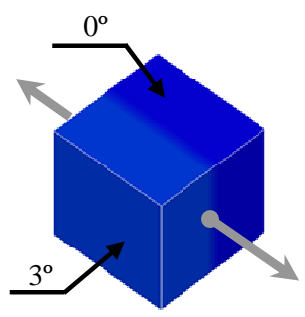

(a-1) $0^{\circ}-3^{\circ}$

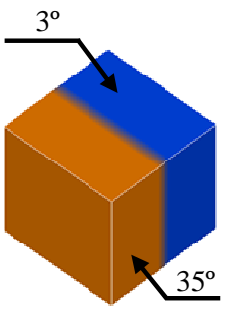

(a-2) $3^{\circ}-35^{\circ}$

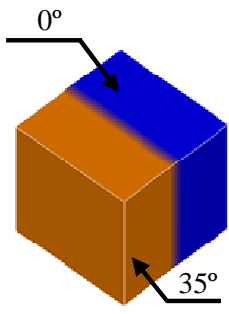

(a-3) $0^{\circ}-35^{\circ}$

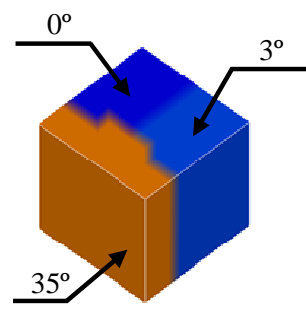

$0^{\circ}-3^{\circ}-35^{\circ}$

(a) Bicrystal models

Fig. 8 Initial crystal orientation angle $\alpha$ distributions of micromodels

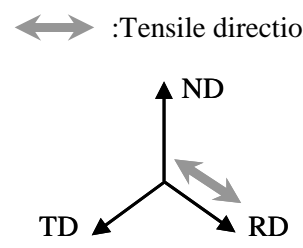

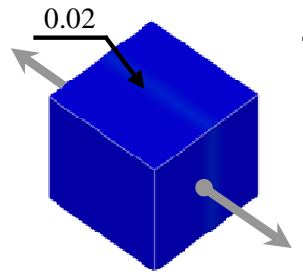

(a-1) $0^{\circ}-3^{\circ}$

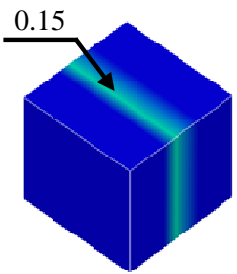

(a-2) $3^{\circ}-35^{\circ}$

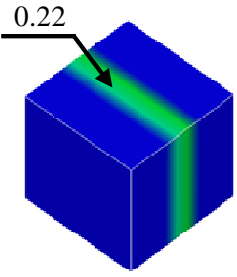

(a-3) $0^{\circ}-35^{\circ}$

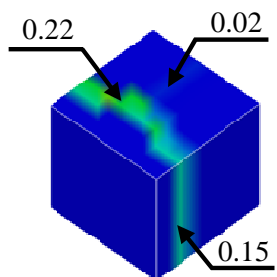

$0^{\circ}-3^{\circ}-35^{\circ}$

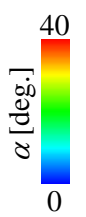

(a) Bicrystal models

Fig. 9 Initial equivalent misorientation distributions of micro models

Table 2 Euler angle $\left(\varphi_{1}, \Phi, \varphi_{2}\right)$ and crystal orientation angle $\alpha$

\begin{tabular}{c|ccc|c}
\hline \hline Unit: [deg.] & $\varphi_{1}$ & $\Phi$ & $\varphi_{2}$ & $\alpha$ \\
\hline Grain 1 & -12.3 & 54.5 & 44.7 & 0.3 \\
\hline Grain 2 & 12.5 & 57.7 & 43.3 & 3.2 \\
\hline Grain 3 & 89.6 & 69.0 & 8.84 & 34.7 \\
\hline
\end{tabular}

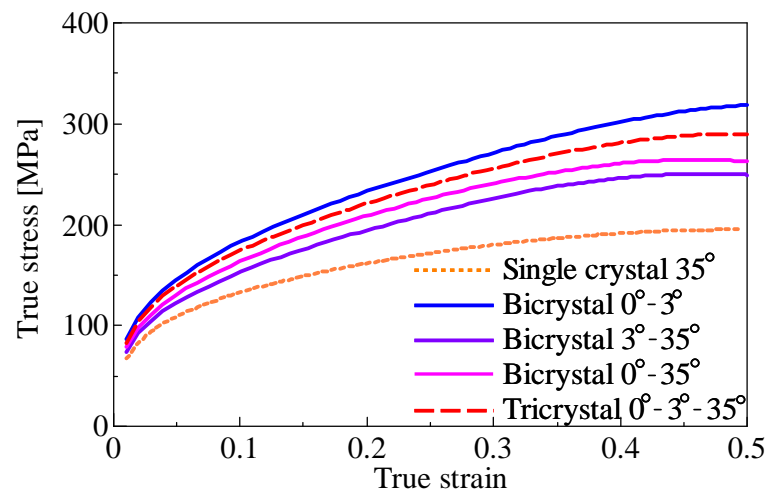

Fig. 10 Relationships between true stress and true strain of FE analyses

デルは（111）面が板面内に多く配向しているため，活動すべり系が多く最も高い応力を示した. 一方で， $\alpha=35^{\circ を 与 え た ~}$

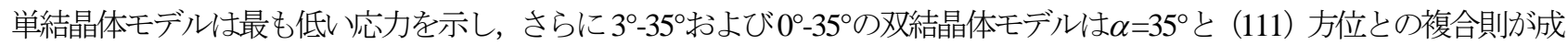

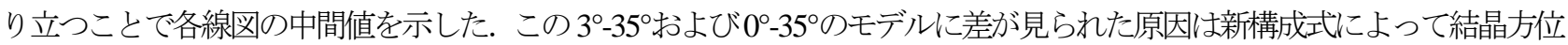
差の影響を考慮できたためと考える.同様に，三結晶体モデルも複合則にしたがう挙動を示した.

図 11 に\{111\}正極点図により集合組織発展結果を示寸，双結晶体 $0^{\circ}-3^{\circ}$ モデルにおいては，初期方位からの変化が顕著で あることが定性的にわかる. 三結晶体モデルおいては, 相互に影響を及ぼし合う結晶が複数存在し, 微視結晶モデル内に三 重点を含んでいることから，最も発展した\{111\}正極点図を示したと考えられる. 


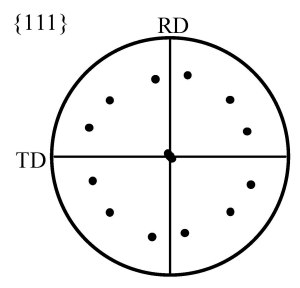

(a-1) Bicrystal $0^{\circ}-3^{\circ}$

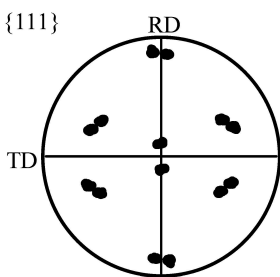

(b-1) Bicrystal $0^{\circ}-3^{\circ}$

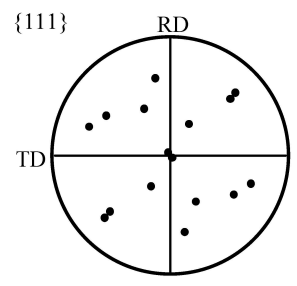

(a-2) Bicrystal $3^{\circ}-35^{\circ}$

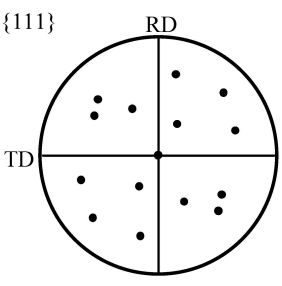

(a-3) Bicrystal $0^{\circ}-35^{\circ}$

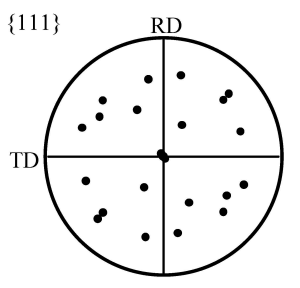

(a-4) Tricrystal $0^{\circ}-3^{\circ}-35^{\circ}$

(a) Initial texture

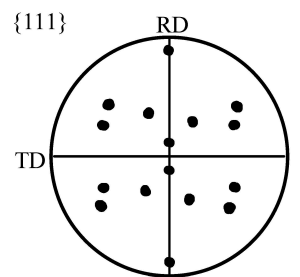

(b-2) Bicrystal $3^{\circ}-35^{\circ}$

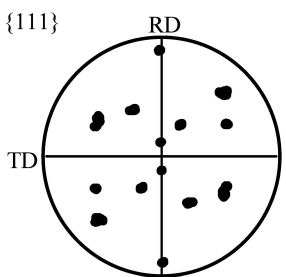

(b-3) Bicrystal $0^{\circ}-35^{\circ}$

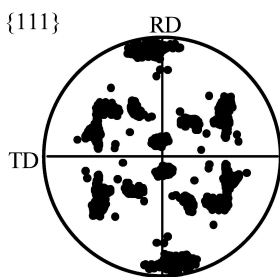

(b-4) Tricrystal $0^{\circ}-3^{\circ}-35^{\circ}$

(b) Texture at 0.5 tensile strain

Fig. 11 Texture evolution on $\{111\}$ pole figures

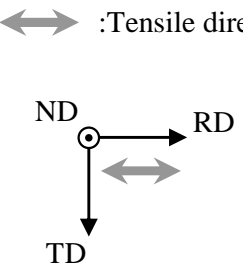

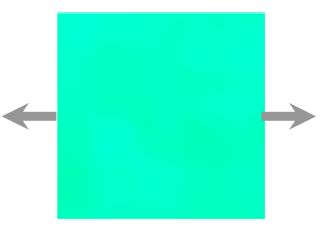

(a-1) $0^{\circ}-3^{\circ}$

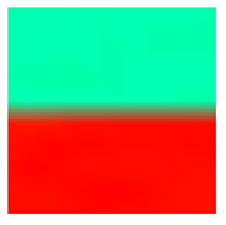

(a-2) $3^{\circ}-35^{\circ}$

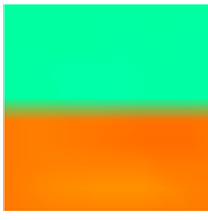

(a-3) $0^{\circ}-35^{\circ}$
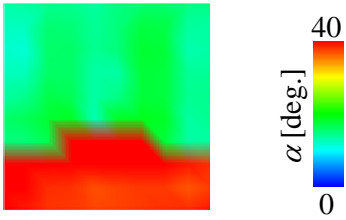

$0^{\circ}-3^{\circ}-35^{\circ}$

(a) Bicrystal models

(b) Tricrystal model

Fig. 12 Distributions of crystal orientation angle $\alpha$ evolutions at 0.5 tensile strain

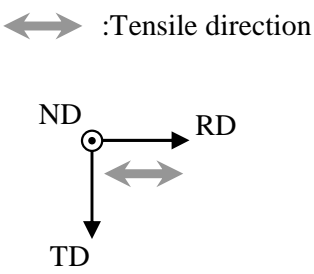

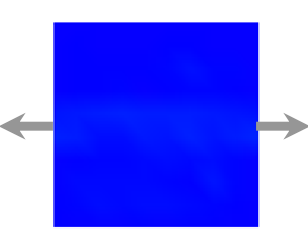

(a-1) $0^{\circ}-3^{\circ}$

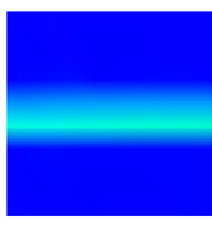

(a-2) $3^{\circ}-35^{\circ}$

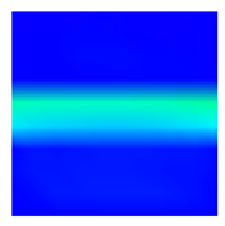

(a-3) $0^{\circ}-35^{\circ}$
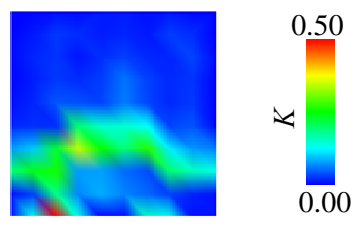

$0^{\circ}-3^{\circ}-35^{\circ}$

(a) Bicrystal models

(b) Tricrystal model

Fig. 13 Distributions of equivalent misorientation evolutions at 0.5 tensile strain

\section{3 -4 結晶方位差発展の解析結果}

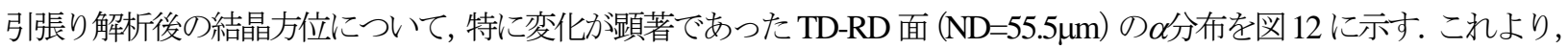
結晶方位回転が初期方位に大きく依存し，同図（a-1）の小傾角を与えたモデルでは，各結晶ともに同一の優先方位に向か って回転したことがわかる，一方，初期に大傾角を与えたモデルでは，同図（a-2），（a-3）に示寸ように変形後において もその粒界は残存し，片方の結晶が顕著に回転する傾向を示寸. 三結晶体モデルにおいては, 双結晶体モデルで予測された 挙動が各粒界で見られた. 小傾角粒界は消㓕し結晶粒結合が，大傾角は残存するという図 5 で確忍された実現象をそれぞれ 再現できた. 図13に相当ミスオリエンテーション $K$ の発展結果を示す.粒界を表す相当ミスオリエンテーション $K$ の值は, 


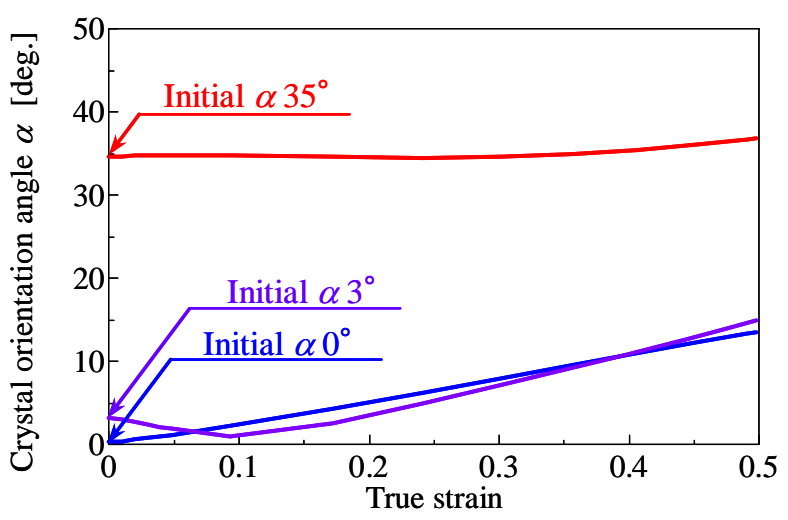

Fig. 14 Crystal rotation histories of tricrystal model

大傾角粒界を持つ双結晶体モデル（a-2），(a-3）および二結晶体モデルの一部では初期と同等または初期より高い值を示し ている. また，三結晶体モデルにおいては，粒内においても相当ミスオリエンテーション $K$ の值の上昇が見られることか らサブグレイン化が確認された. 一般にある一定以上のひずみを金属材料に与えた場合, 方位差が 15 未満の亜粒界が発生 することが知られており，本解析手法によって高精度に方位回転が予測できた. 図 14 に三結晶体モデルにおける各結晶粒 の方位回転履歴を示す．これより，特定の結晶粒がより顕著に回転することがわかる.

本研究て提案した結晶方位差理論に基づく新硬化発展方程式を用いることにより, 結晶方位差によって硬化発展および結 晶方位回転の傾向が大きく異なることが記述できた. 今後, 本解析手法を実金属材料に基づいた多結晶微視モデルに適用す ることで，金属材料の変形挙動を実現象に忠実に予測することが可能になると考えられる.

\section{4. 結}

本研究では, 結晶方位差理論を導入した新硬化発展方程式を採用した結晶塑性構成式を提案した. 初期結晶方位分布を硬 化発展に反映させることにより, 塑性変形誘起の結晶集合組織発展予測に有力な手法となると考える. 双結晶体および二結 晶体の塑性変形解析を行うことで結晶方位差発展評価を行った結果, 塑性変形の進行に伴い小傾角粒界は消滅する傾向およ び大傾角粒界が維持される傾向が確認された. 以上より, 新たに提案した新硬化発展方程式を用いることによって結晶粒界 挙動およひ硬化の影響を考慮した結晶方位差発展解析が可能となった.

本研究の一部は, 天田金属加工機械技術振興財団平成 20 年度一般研究助成, および文部科学省科学研究費補助 金（若手研究 B, 21760088）の助成を受けたものである.ここに記して謝意を表す.

\section{文献}

(1) Taylor, G.I., “Plastic Strain in Metals”, Journal of the Institute of Metals, Vol. 62 (1938), pp. 307-324.

(2) 佐々木克彦, 石川博將, “転位密度を考慮した構成モデルによる二軸ラチェット変形シミュレーション”, 日本 機械学会論文集 A 編, Vol. 68, No. 665 (2002), pp. 1169-1174.

(3) Ohashi, T., "Finite-element Analysis of Plastic Slip and Evolution of Geometrically Necessary Dislocation in Fcc Crystals”, Philosophical Magazine Letters, Vol. 75, No. 2 (1997), pp. 51-57.

(4) Steinman, P., Kuhl, E. and Stein, E., "Aspects of Non-associated Single Crystal Plasticity: Influence of Non-schmid Effects and Localization Analysis”, International Journal of Solids Strictures, Vol. 35, No. 33 (1998), pp. 4437-4456.

(5) Ashby, M.F., “The Deformation of Plastically Non-homogeneous Materials”, Philosophical Magazine, Vol. 21, No. 170 (1970), pp. 399-424.

(6) 大橋鉄也, “結晶の塑性すべりと転位蓄積の解析へのメゾスケールアプローチ”，日本機械学会論文集 A 編, Vol. 68, No. 675 (2002), pp. 1490-1497.

(7) Busso, E.P., Meissonnier, F.T. and O’Dowd, N.P., “Gradient-dependent Deformation of Two-phase Single Crystals", Journal of Mechanics and Physics of Solids, Vol. 48 (2000), pp. 2333-2361. 
(8) Shizawa, K., Kikuchi, K. and Zbib, M.H., “A Strain-gradient Thermodynamic Theory of Plasticity Based on Dislocation Density and Incompatibility Tensors”, Journal of Materials Science and Engineering, Vol. A309, No. 310 (2001), pp. $416-419$.

(9) Aoyagi, Y. and Shizawa, K., "Multiscale Crystal Plasticity Modeling Based on Geometrically Necessary Crystal Defects and Simulation on Fine-graining for Polycrystal”, International Journal of Plasticity, Vol. 23 (2007), pp. 1022-1040.

(10) Fleck, N.A., Muller, G.M. and Hutchinson, J.W., "Strain Gradient Plasticity: Theory and Experiment”, Acta Metallurgica et Materialia, Vol. 42, No. 2 (1994), pp. 475-487.

（11）比嘉吉一，澤田幸秀，冨田佳宏，“多結晶金属材料の特徵長さ依存性挙動の数值シミュレーション”，日本機械学 会論文集 A 編，Vol. 69, No. 697 (2003), pp. 523-529.

(12) 仲町英治, 廣瀬学, 河森洋一, 中西瑞樹, 森本秀夫, “純アルミニウム単結晶の準単純せん断塑性変形実験による 寸法効果の検討”，日本機械学会論文集 A 編，Vol. 71, No. 701 (2005), pp.51-58.

(13) 仲町英治, 廣瀬学, 森本秀夫, “非シュミット則を考慮した結晶塑性構成式の提案と実験検証”, 日本機械学会論文 集 A 編，Vol. 71, No. 701 (2005), pp.59-65.

(14) 坪井善勝, 田治見宏, 角野晃二, “応用数学”, コロナ社, (1969), pp. 374-415.

(15) Nakamachi, E., Tam, N.N. and Morimoto, H., "Multi-scale Finite Element Analyses of Sheet Materials by using SEM-EBSD Measured Crystallographic RVE Models”, International Journal of Plasticity, Vol. 23, No. 3 (2007), pp. 450-489.

(16) Harder, J., “Crystallographic Model for the Study of Local Deformation Processes in Polycrystals”, International Journal of Plasticity, Vol. 15 (1999), pp. 605-624.

(17) Pan, J. and Rice, J.R., "Rate Sensitivity of Plastic Flow and Implications for Yield-surface Vertices", International Journal of Solids and Structures, Vol. 19 (1983), pp. 973-987.

(18) Zhou, Y., Neale, K. W. and Toth, L.S., “A Modified Model for Simulating Latent Hardening During the Plastic Deformation of Rate-dependent FCC Polycrystals”, International Journal of Plasticity, Vol. 9 (1993), pp. 961-978.

(19) Lange, F.F., “Mathematical Characterization of a General Bicrystal”, Acta Materialia, Vol. 15 (1996), pp. $318-331$.

(20) Needleman, A., "Finite Element for Finite Strain Plasticity Problems”, Proceedings of the Workshop on Plasticity of Materials at Finite Strain, (1981), pp. 1-11.

(21) Asaro, R.J. and Needleman, A., “Texture Development and Strain hardening in Rate Dependent”, Acta Metallurgica, Vol. 33, No. 6 (1985), pp. 923-953.

(22) Asaro, R.J., “Crystal Plasticity”, Journal of Applied Physics, Vol. 50 (1983), pp. 921-934.

(23) Hill, R., “Theoretical Plasticity of Textured Aggregates”, Mathematical Proceedings Cambridge Philosophical Society, Vol. 85 (1979), pp. 179-191. 